\title{
Anadolu Folklorik Tıbbında Siğil Tedavisinde Kullanılan Yılan Gömleklerinin Element İçeriğinin Belirlenmesi*
}

\section{Determination of The Element Content of Shed Snake Skin Used in The Papilloma Treatment of Anatolian}

Folkloric Medicine

Veli Sakallıi, Ülkü Çömelekoğluii

i Dönem 5 Öğrencisi, Mersin Üniversitesi Tıp Fakültesi

ii Prof.Dr. Mersin Üniversitesi Tıp Fakültesi Biyofizik Anabilim Dalı https://orcid.org/0000-0001-8060-6333

öz

Giriş: Yılanların deri değiştirmesi yaşam döngülerinin dinamik bir parçasıdır. Sağılılı yılanlar yılda üç ya da dört kez deri değiştirirler. Doğaya bırakılan bu deriler yılan gömleği olarak adlandırılır. Yılan gömlekleri antik dönemden bu yana folklorik tıpta çeşitli hastalıkların tedavisinde kullanılmaktadır. Bu çalışmada Anadolu folklorik tıbbında siğil tedavisinde kullanılan yılan gömleklerinin element içeriğinin belirlenmesi amaçlanmıştır.

Metod: Çalışmada Kahramanmaraş kırsalından toplanan Dolichophis jugularis (Karayılan) $(\mathrm{n}=6)$ ve Malpolon insignitus (Çukurbaşı yılan) $(n=6)$ türlerine ait toplam 12 adet yılan gömleği kullanılmıştır. Yılan gömlekleri 2017 yılı Nisan-Mayıs aylarında Veli Sakallı tarafından toplanmıştır. Yılan gömleklerinin element içeriği ve element derişimleri indüktif eşleşmiş plazma kütle spektrometresi kullanılarak belirlenmiştir.

Bulgular: Her iki türe ait gömleklerde toplam 21 makro ve mikroelement ve derişimleri saptanmıştır. Türler arasında magnezyum, titanyum, mangan, demir ve nikel elementlerinin derişimleri arasındaki fark istatistiksel olarak önemli bulunmuş, diğer element derişimleri arasında ise önemli bir fark gözlenmemiştir.

Tartışma: Çalışma sonunda Anadolu folklorik tıbbında siğil tedavisinde kullanılan Dolichophis jugularis ve Malpolon insignitus türlerine ait yılan gömleklerinin zengin bir element içeriğine sahip olduğu ve bu içeriğin siğile neden olan virüsü inaktive ederek siğili tedavi edebildiği düşünülmüştür. Elde edilen sonuçlar siğil tedavisinde kullanılabilecek yeni ilaçların sentez edilme çalışmalarına katkıda bulunma potansiyeline sahiptir.

Anahtar Kelimeler: Anadolu folklorik tıbbı, yılan gömleği, papilloma tedavisi, element analizi

ABSTRACT

Introduction: The shedding process of snakes is a dynamic part of their life cycles. Healthy snakes shed their skin three or four times a year. The shedding skin is left to nature and is called shed snake skin. Shed snake skin have been used in the treatment of various diseases in folkloric medicine since ancient periods. In this study, it was aimed to determine the elemental content of shed snake skin used in papilloma treatment in Anatolian folkloric medicine.

Method: In the present study, a total of 12 shed snake skins collected from the countryside of Kahramanmaras from the Dolichophis jugularis $(n=6)$ and Malpolon insignitus $(n=6)$ species were used. Shed snake skins were collected by Veli Sakallı in April-May 2017. The elemental content and the elemental concentrations of shed snake skins were determined using inductively coupled plasma mass spectrometry.

Result: A total of 21 macro and microelement and concentrations were determined in the shed skins of both species. The difference between the concentrations of magnesium, titanium, manganese, iron, and nickel elements was found to be statistically significant among the species and no significant difference was observed between the other element concentrations.

Discussion: As a result of the current study, it was thought that the shed skins of Dolichophis jugularis and Malpolon insignitus species used in the treatment of papilloma in Anatolian folkloric medicine has contents rich in elements and these contents may treat the papilloma by inactivating the virus causing the papilloma. The results have the potential to contribute to the synthesis of new drugs that can be used in the treatment of papilloma.

Key words: Anatolian folkloric medicine, shed snake skin, papilloma treatment, elemantal analysis

*Lokman Hekim Dergisi, 2019; 9 (3): 312-316

DOI: $10.31020 /$ mutftd.563870

e-ISSN: $1309-8004$

Geliş Tarihi - Received: 13 Mayıs 2019; Kabul Tarihi - Accepted: 25 Temmuz 2019

iletişim - Correspondence Author: Ülkü Çömelekoğlu <ucomelek@yahoo.com> 


\section{GíRiş}

Birçok uygarlığa ev sahipliği yapan Anadolu köklü bir folklorik tıp geleneğine sahiptir. Folklorik tıp, halkın herhangi bir yardım almaksızın kendini tedavi etme yöntemlerini içerir; bunların bir kısmı gelişmiş, bir kısmı ise ilkel düzeyde kalmıştır. illkel şekiller halk arasında gelenekler yardımıyla yaşamaktadır. Folklorik tıp çağdas bilimsel tıbba bir seçenek olma amacı gütmeksizin, varlığını çağlar boyunca sürdürüp gelmiş kültürel bir kalıttır. Folklorik tıbbın yöntemleri, deneyimsel gözlemlere dayanır. ${ }^{1}$

Yeni ilaçların geliştirilmesi çalışmalarına dünyada her yıl milyonlarca dolar para harcanmaktadır. Dünya Sağlık Örgütü’nün ilaç kullanımı için seçtiği 252 temel kimyasalın \% 11'i bitkisel kökenli, \% 8.7'si ise hayvansal kökenlidir. Geleneksel yöntemlerden yola çıkarak ilaç sentez edilmesi çalışmaları son yıllarda büyük önem kazanmıştır. Bu çalışmalarda büyük oranda etnobiyolojik verilerden yararlanılmaktadır. ${ }^{2}$

İnsanda siğil oluşumuna neden olan virüs insan papilloma virüs (HPV) olarak bilinir. Papilloma virüsleri, cildi ve mukoza zarlarını infekte etmeyen, deoksiribonükleik asit (DNA) virüsleridir. HPV yaklaşık 120 suştan oluşan bir papilloma virüs grubuna aittir. ${ }^{3,4}$ Ellerde ve ayaklarda siğile neden olanlar genellikle zararsız olarak bilinir. Bir kısmı ise genital siğillere (kondiloma aküminatı) neden olur ve serviks, vulva, vajina, penis, anüs ve orofarinks kanserlerine yol açabilir. ${ }^{5}$

Antik dönemden bu yana yılanlar farklı vücut yapısı, gizemli yaşam tarzı ve olası bir tehdit oluşturmalarından dolayı çeşitli inanış ve uygulamalarda yer almaktadır. Bu uygulamalar arasında yılan gömleklerinin sedef hastalığı, akne, glokom, egzama, siğil gibi farklı hastalıkların tedavisinde kullanımı da bulunur. ${ }^{6}$

Yılanlar, derilerinin en dış tabakasını periyodik olarak değiştirir. Bu değiştirme yılanların hasarlanmış ve yıpranmış deriden kurtularak parazitlerinden kurtulmalarına ve büyümelerine olanak sağlar. ${ }^{7}$ Bu olaya deri değiştirme, atılan bu bölüme de yılan gömleği adı verilir. Yılan gömleğinin, epidermisin özellikle en dış katmanı olan stratum corneum'un morfolojik kimliği olduğu belirtilmektedir. ${ }^{8}$ Stratum corneum'un dış tabakası, içte gelişen yenisi ile ayrılır ve bu ara bölmeye lenfatik sıvı dolar. Yılanlarda epidermis gözün üst tarafını saydam bir kapak şeklinde örter. Bu sıvı eski ve yeni oluşan kapak arasına girdiğinde, deri değiştirme öncesinde yılanlarda gözler saydamlığını kaybeder. Deri değiştirme öncelikle baş kısmından başlar. Musculus jugularis'in kontraksiyonu ile Jugular venalar sıkılır ve baş kısmında kan basıncı artar, hacim büyür ve eski deri atılmağa başlar. Bacaksız reptillerde de deri, yılan gömleğinde olduğu gibi tek parça halinde sıyrııır. ${ }^{9}$ Yılanların periyodik olarak değiştirdiği bu gömlekler Anadolu'da uzun yıllardan beri siğil tedavisinde kullanılmaktadır. ${ }^{10}$ Doğu Anadolu bölgesinde yılan gömleği toz haline getirilerek çorbaya katılarak ya da balla karıştırılarak siğili olan hastaya yedirilmektedir ya da tuzsuz tereyağı ile karıştırılarak siğil üzerine dıştan sürülmektedir. Bir başka yöntem ise yılan gömleklerinin yakılması ve siğilli yerlerin dumana tutulmasıdır. ${ }^{7}$ Kırgız halk hekimleri de yılan gömleğini genellikle siğil, sivilce, egzama, uyuz, yara vb. gibi cilt hastalıklarını tedavi etmekte kullanmaktadırlar. Tedavi sırasında bazı bölgelerde yılan gömleği suda kaynatılarak suyu hastaya içirilmekte ya da ya da toz haline getirerek hastalığın bulunduğu yere sürmekte ya da serpmektedirler. ${ }^{11}$

Kahramanmaraş köylerinde yılan gömlekleri siğil tedavisinde uzun yıllardan bu yana kullanılmaktadır. Tedavinin etkisinin yılan türlerine göre değiştiği belirtilmektedir. Yöre halkının verdiği bilgilere göre karayılan gömleği, siğili 3-4 ay gibi bir sürede tedavi ederken, boz yılan gömleğinde bu süre 6-8 ay ve ok yılanı gömleğinde ise 8-10 ay gibi bir süreyi kapsamaktadır (Ali Tutay, Veteriner Hekim, Çağlayancerit, Kahramanmaraş, 15 Şubat 2017). Ayrıca karayılan gömleği tedavisi sonucunda yoğun siğil döküntüleri görülürken, diğerlerinde etkisinin daha az olduğu bildirilmiştir (Ali Tutay, Veteriner Hekim, Çağlayancerit, Kahramanmaraş, 15 Şubat 2017).

Antik dönemden bu yana ilaç elde edilmesinde önemli bir kaynak olarak kullanılan bitki ve hayvan materyallerinin etkinliği, güvenilirliği, kalitesi gösterildikten ve standardizasyonu sağlandıktan sonra tedavide kullanılması gerekir. ${ }^{12}$ Aksi halde istenmeyen sonuçlara yol açma olasılı̆ı yüksektir. Bunun için gelişen teknolojiyi kullanarak bitki ya da hayvanlardan elde edilen materyalin etken maddesinin elde edilmesi ve bunun sentetik sentezinin yapılması ve test edilmesi önemlidir. ${ }^{12} \mathrm{Bu}$ araştırmada Kahramanmaraş bölgesinden toplanan iki farklı türe (Dolichophis jugularis ve Malpolon insignitus) ait yılan 
gömleklerinin element analizinin yapılması ve bu yolla siğil tedavisinde kullanılacak yeni bir ilacın sentezine yönelik çalışmalara katkıda bulunulması hedeflenmiştir.

\section{YÖNTEM}

\section{Yılan Gömleklerinin toplanması}

Yılan gömlekleri ( $n=12$ ) Kahramanmaraş Çağlayancerit ilçesinin kırsalından toplandı (Şekil 1) ve kullanılıncaya kadar şeffaf zarflar içinde kuru ve serin yerde saklandı. Yılan gömlekleri 2017 yılı Nisan-Mayıs aylarında Veli Sakallı tarafından toplandı. Toplanan yılan gömleklerin Dolichophis jugularis $(n=6)(S$ ekil 1A) ve Malpolon insignitus ( $n=6$ ) (Şekil 1B) türlerine ait olduğu gömlekler üzerindeki folidosis karakterlerine bakılarak saptandı. Yılan gömlekleri uzunlukları, karın tarafında vücudun orta bölgesinde ventralia denen plakların sayısı ve kuyruk altı plak sayısı olarak bilinen subcaudalia sayısı bakımından incelendi (Doç.Dr. Aziz Avcı). Dolichophis jugularis gömlekleri $n_{1}=170 \mathrm{~cm} \times 204$ adet $\times 124$ adet (uzunluk $\times$ ventralia $\times$ subcaudalia) $\mathrm{n}_{2}=120 \mathrm{~cm} \times 186$ adet $\times 102$ adet, $\mathrm{n}_{3}=150 \mathrm{~cm} \times 198$ adet $\times 118$ adet subcaudalia sayısına sahipken Malpolon insignitus gömlekleri $\mathrm{n}_{4}=190 \mathrm{~cm} \times 212$ adet $\times 114$ adet, $\mathrm{n}_{5}=110 \mathrm{~cm} \times 178$ adet $\times 84$ adet, $\mathrm{n}_{6}=100 \mathrm{~cm} \times 164$ adet $x 76$ adet subcaudalia sayısına sahipti.
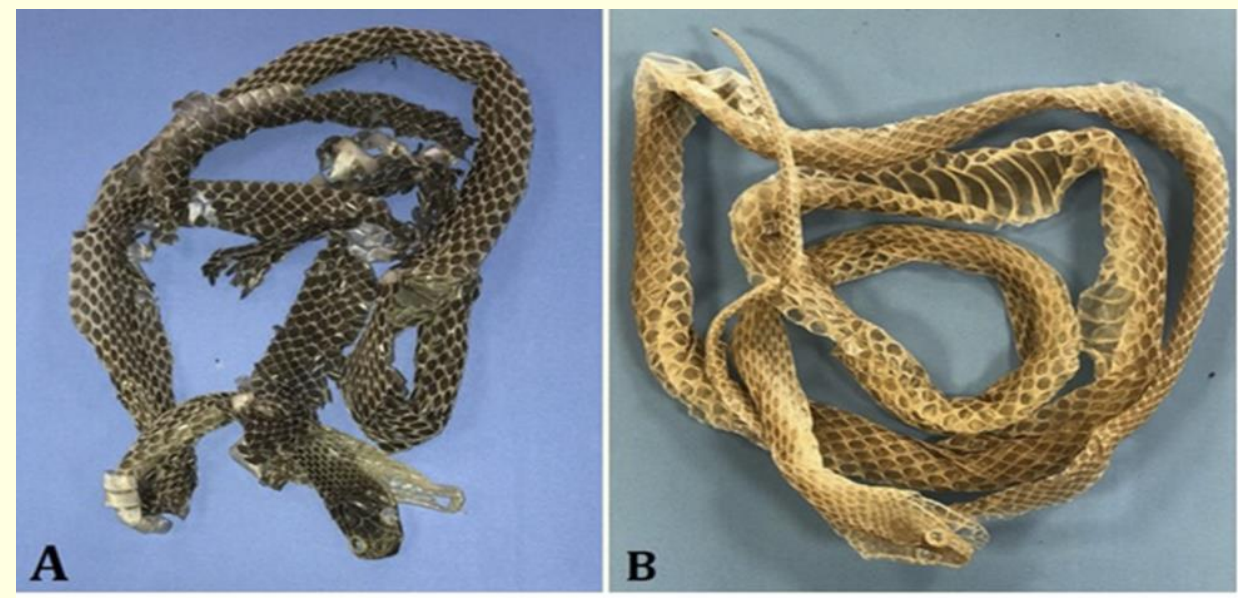

Şekil 1. Dolichophis jugularis (A) ve Malpolon insignitus (B) türlerine ait yılan gömlekleri

\section{Yılan gömleklerinin endüktif eşleşmiş plazma kütle spektrometresi (ICP-MS) ile analizi}

Yılan gömleklerinin elementel analizi Mersin Üniversitesi İleri Teknoloji Araştırma ve Uygulama Merkezinde bulunan ICP-MS (Agilent 7500ce, Santa Clara, CA, USA) ile yapıldı. Yılan gömleklerinin gövde kısımdan $1 \mathrm{gr}$ ağırlığında örnekler alındı. Alınan örnekler Hidroklorik asit ve Nitrik asitin sırasıyla 3:1 oranındaki karışımında 24 saat bekletildikten sonra 30 dakika $180{ }^{\circ} \mathrm{C}$ da mikrodalgada bekletildi. Bu işlemi takiben çözeltiden mikropipet aracılığıyla $1 \mathrm{~mL}$ alınıp saf su ile $10 \mathrm{ml}$ ye tamamlandı ve elementel analizi yapılmak üzere cihaza yerleştirildi. ICP-MS indüktif eşleşmiş plazma ve kütle spektrometresi olmak üzere iki ünitenin bileşiminden oluşmuştur. Yılan gömleklerindeki elementler ICP'de iyonlaştırıldıktan sonra kütle spektroskopisine (MS) gönderildi ve burada kütle/yük (m/z) oranlarına göre ayrılıp ölçüldü.

\section{İstatistiksel Analiz}

İstatistiksel analiz için SPSS (IBM SPSS Statistics 20, İstanbul, Türkiye) istatik paket programı kullanıldı. Verilerin normal dağılıma uygunluğu Kolmogorov-Smirnov testi ile gösterildikten sonra ölçülen element miktarları açısından iki tür arasında önemli fark olup olmadığı student-t testi ile test edildi. Veriler ortalama \pm standart sapma olarak ifade edildi. İstatistiksel anlamlılı̆ın sınırı $p<0.05$ olarak belirlendi. 


\section{BULGULAR}

Yılan gömleklerinin içeriklerini gösteren ICP-MS sonuçları aşağıda sunulmuştur (Tablo 1). Tablodan da görüldüğü gibi yılan gömlekleri sodyum (Na), magnezyum (Mg), alüminyum (Al), fosfor (P), potasyum (K), kalsiyum (Ca) gibi makro elementlerin yanı sıra titanyum (Ti), mangan ( $\mathrm{Mn})$, demir (Fe), nikel (Ni), bakır (Cu), çinko $(\mathrm{Zn})$, stronsiyum (Sr) ve baryum (Ba) gibi eser elementleri içermektedir. Tablodaki elementlere ek olarak her iki türe ait yılan gömlekleri $1 \mathrm{ng} / \mathrm{g}^{\prime}$ dan küçük miktarlarda bor (B), selenyum (Se), molibden (Mo), kadmiyum (Cd), antimon ( $\mathrm{Sb})$, talyum ( $\mathrm{Tl}$ )ve kurşun $(\mathrm{Pb})$ içermektedir. Mevcut elementlerin miktarları açısından Dolichopis jugularis ve Malpolon Insignitus türleri arasında yapılan karşılaştırmada iki tür arasında sadece $\mathrm{Mg}, \mathrm{Mn}, \mathrm{Ti}, \mathrm{Fe}$ ve Ni elementlerinin miktarlarının istatistiksel olarak önemli olduğu bulunmuştur $(\mathrm{p}<0.05)$. Dolichopis jugularis türünde Malpolon insignutus türüne göre $\mathrm{Mg}$ oranı $2.64, \mathrm{Ti}$ oranı $1.96, \mathrm{Mn}$ oranı 1.79 , Fe oranı 2.57 ve Ni oranı 2.82 kat daha fazladır.

Tablo 1. Dolichopis jugularis ve Malpolon insignutus türlerine ait yılan gömleklerinin elementsel analizi.

\begin{tabular}{|c|c|c|c|}
\hline Element miktarı $(\mu \mathrm{g} / \mathrm{g})$ & $\begin{array}{c}\text { Dolichopis jugularis } \\
\text { Ortalama } \pm \text { standart sapma }\end{array}$ & $\begin{array}{c}\text { Malpolon Insignitus } \\
\text { Ortalama } \pm \text { standart sapma }\end{array}$ & P değeri* \\
\hline $\mathrm{Na}$ & $3233,1 \pm 584,1$ & $3533,1 \pm 660,0$ & 0,408 \\
\hline $\mathrm{Mg}$ & $1958,6 \pm 1032,8$ & $740,5 \pm 114,4$ & 0,035 \\
\hline $\mathrm{Al}$ & $2622,1 \pm 1500,2$ & $1367,9 \pm 582,8$ & 0,085 \\
\hline$P$ & $2745 \pm 179,6$ & $3050 \pm 217,74$ & 0,672 \\
\hline K & $3653,2 \pm 100,85$ & $4950 \pm 732,7$ & 0,129 \\
\hline $\mathrm{Ca}$ & $4029,4 \pm 1844,5$ & $3107,2 \pm 347,6$ & 0,077 \\
\hline $\mathrm{Ti}$ & $82,66 \pm 83,78$ & $41,96 \pm 17,03$ & 0,037 \\
\hline $\mathrm{Mn}$ & $28,90 \pm 12,54$ & $16,1 \pm 2,86$ & 0,044 \\
\hline $\mathrm{Fe}$ & $2171,8 \pm 1228,5$ & $843,1 \pm 367,4$ & 0,05 \\
\hline $\mathrm{Ni}$ & $15,06 \pm 11,08$ & $5,33 \pm 1,23$ & 0,038 \\
\hline $\mathrm{Cu}$ & $12,43 \pm 0,68$ & $12,94 \pm 0,89$ & 0,582 \\
\hline $\mathrm{Zn}$ & $83,35 \pm 5,45$ & $91,03 \pm 13,8$ & 0,263 \\
\hline $\mathrm{Sr}$ & $22,44 \pm 6,96$ & $12,66 \pm 1,67$ & 0,151 \\
\hline $\mathrm{Ba}$ & $9,88 \pm 2,43$ & $6,32 \pm 0.70$ & 0,153 \\
\hline
\end{tabular}

*istatistiksel anlamlıı̆ın sınıı $p<0.05$ olarak belirlenmiştir.

\section{TARTIŞMA}

Bu çalışmada folklorik tıpta siğil tedavisinde kullanılan Dolichopis jugularis ve Malpolon Insignitus türlerine ait yılan gömleklerinin elementel analizi ICP-MS kullanılarak yapılmış ve bu yöntemle yılan gömleklerinde 21 elementin varlığı ve derişimi saptanmıştır. Bu elementlerden bir bölümü ( $\mathrm{Na}, \mathrm{K}, \mathrm{Ca}, \mathrm{P}, \mathrm{Mg}$ ) makroelementler olarak isimlendirilen elementler grubunda yer alırken bir bölümü de $(\mathrm{Zn}, \mathrm{Cu}, \mathrm{Ti}, \mathrm{Mn}, \mathrm{Fe}, \mathrm{Sr}, \mathrm{Ba}, \mathrm{Ni})$ mikroelementler (eser elementler) olarak isimlendirilen elementler grubundandır.

Yapılan analiz sonucunda Kahramanmaraş kırsal bölgesinden toplanan Dolichopis jugularis ve Malpolon Insignitus türlerine ait yılan gömleklerinin özellikle eser elementler açısından zengin olduğu saptanmıştır. Yılan gömleklerinin siğil tedavisindeki başarısının zengin eser element içeriğiyle ilişkili olabileceği düşünülmüştür. Çinko, bakır, mangan, selenyum gibi eser elementler immün sistemi modüle edici özelliğe sahiptir ve bu özellikleriyle çeşitli viral enfeksiyonlara karşı duyarlılı̆ı etkileyebilirler. ${ }^{13}$ Bu elementler vücudu patojen ajanlara karşı koruyan fagositik hücre üretiminde ve zararlı etkenin yok edilmesinde önemli rol oynarlar. ${ }^{14}$ Özellikle çinko bu tür hücrelerin aktivasyonunu arttırır. ${ }^{13}$ Çinko, timidin kinaz, ribonükleaz ve RNA ve DNA polimerazları dahil olmak üzere birçok enzim için bir kofaktördür. ${ }^{14}$ Bu enzimlerin tümü hücre bölünmesi için önemlidir. Ek olarak çinko T hücresi olgunlaşmasında kilit rol oynayan peptid hormon timulin sentezi için gerekli bir kofaktördür. ${ }^{14}$ Antioksidan sistem enzimlerinden süperoksit dismutaz enziminin aktivasyonunda kofaktör olarak rol oynayan bakır elementinin ise virüslerın inaktivasyonunda rol oynadığı bildirilmiştir. ${ }^{15,16}$ Bu çalışmada Dolichopis jugularis ve Malpolon Insignitus türlerine ait yılan gömleklerinde bakır derişimi sırasıyla $12,43 \pm 0,68$ ve $12,94 \pm 0,89 \mu \mathrm{g} / \mathrm{g}$ olarak ölçülmüştür. Bu bakır düzeyi siğil oluşumunda rol oynayan HPV virüsleri inaktive ederek siğil tedavisinde önemli bir rol oynayabilir. Bu etkinin yine her iki 
türe ait yılan gömleklerindeki $83,35 \pm 5,45$ ve $91,03 \pm 13,8 \mu \mathrm{g} / \mathrm{g}$ derişimindeki çinkonun fagositik hücreleri aktive edici özelliğiyle sinerjik etki oluşturarak HPV virüslerinin etkisizleştirilmesinde rolü olabilir.

\section{SONUÇ}

Bu çalışmayla Kahramanmaraş kırsalından toplanan ve folklorik tıpta siğil tedavisinde kullanılan Dolichopis jugularis ve Malpolon Insignitus türlerine ait yılan gömleklerinin zengin bir element içeriğine sahip olduğu saptanmıştır. Element derişimi türe bağlı değişiklik göstermektedir. Bu elementlerin özellikle de çinko, bakır gibi eser elementlerin siğil oluşumuna yol açan HPV'u inaktive ederek siğilleri tedavi etmede rolü olabileceği düşünülmüştür. Ancak yılan gömleği ya da diğer benzer materyaller bilimsel teknikler kullanarak ilaç hammaddesi haline getirilmeden, etkililiği, güvenliliği, kalitesi ve standardizasyonu sağlanmadan ilaç yerine kullanılmamalıdır. Bizim bilgilerimize göre bu çalışma yılan gömleklerinde element analizinin yapıldığı ilk çalışmadır. Bu çalışmayla toplumumuzda sıkça rastlandığı gibi hayvan veya bitkisel materyallerinin doğrudan kullanımı yerine bilimsel yöntemler kullanılarak içerik analizinin yapılabileceği ve bu analiz sonuçlarının tedavide kullanılabilecek yeni ilaçların geliştirilmesine katkıda bulunma potansiyeline sahip olduğu gösterilmiştir.

\section{Teşekkür}

Bu çalışma 1919B011603620 başvuru numarasıyla TÜBITAK 2209 Lisans Öğrencileri Araştırma Projeleri Programı kapsamında desteklenmiştir. Yazarlar yılan gömleklerinin tür tayinini yapan Aydın Adnan Menderes Üniversitesi Fen Edebiyat Fakültesi Zooloji Anabilim Dalı öğretim üyesi Doç.Dr. Aziz Avcı́ya teşekkür ederler.

\section{KAYNAKLAR}

1. Oğuz NY. Toplum, bilim ve tıp etiği açısından alternatif tıp ve halk tıbbı. Bilim ve Ütopya Dergisi 1996;25:36-7.

2. Costa-Neto EM. Animal-based medicines: biological prospection and the sustainable use of zootherapeutic resources. An Acad Bras Cienc 2005;77(1):33-43.

3. Avcı GA, Bozdayı G. İnsan papilloma virüsü. Kafkas J Med Sci 2014;3:136-144.

4. Şahiner F, Şener K. Human Papilloma Virüs Enfeksiyonları, Risk Faktörleri ve Koruyucu Önlemler. TAF Prev Med Bull 2013;12(6):715-722.

5. Munoz N. et al. Epidemiologic classification of human papillomavirus types associated with cervical cancer. N Engl J Med 2003;348(6):518-527.

6. Mukherjee S, Gomes A, Dasgupta SC. Zoo therapeutic uses of snake body parts in folk traditional medicine. J Zool Res 2017;1:1-9.

7. Greene HW. Snakes: the evolution of mystery in nature. University of California Press; California, 1997.

8. Gray BS. Shed snakeskin Identification: a guide to snakeskins found in Pennsylvania. Pennsylvania Amphibian and Reptile Survey, 2015.

9. Budak A, Göçmen, B. Herpetoloji. Ege Üniversitesi, 2014.

10. Tataroğlu ET. Anadolu tıbbi follorunda cilt hastalıkları ve tedavi uygulamaları. Yüksek Lisans Tezi, İstanbul Üniversitesi Sosyal Bilimler Enstitüsü, 2014.

11. Orozobaev M. Kırgız halk inancı ve halk hekimliği uygulamalarında yılan. Karadeniz 2012;15:1-17.

12. Bitkisel ürünler ve sağlık: Bilimsel çerçeve ve etik açısından yaklaşım. Türk Tabibler Birliği Merkez Konseyi, 2012.

13. Chaturvedi UC, Shrivastava R, Upreti RK. Viral infections and trace elements: a complex interaction. Current Sci 2004; 87(11):1536-1554.

14. Beck MA. Trace minerals, immune function, and viral evolution, In: Military Strategies for Sustainment of Nutrition and Immune Function in the Field. Institute of Medicine, Committee on Military Nutrition Research. National Academies Press.1999. pp. 337-359.

15. Sagripanti JL. et al. Mechanism of copper-mediated inactivation of herpes simplex virus. Antimicrob Agents Chemother 1997;41(4):812-817.

16. Noyce JO, Michels $\mathrm{H}$, Keevil CW. Inactivation of influenza A virus on copper versus stainless steel surfaces. Appl. Environ. Microbiol 2007;73(8):2748-2750. 